\title{
Indirect power control of DFIG based on wind turbine operating in MPPT using backstepping approach
}

\author{
Yahya Dbaghi, Sadik Farhat, Mohamed Mediouni, Hassan Essakhi, Aicha Elmoudden \\ Laboratoire des Sciences de l'Ingénieur et Management de l'Energie (LSIME) ESTA Ibn Zohr University, \\ Agadir, Morocco
}

\begin{tabular}{l} 
Article Info \\
\hline Article history: \\
Received Jul 15, 2020 \\
Revised Dec 12, 2020 \\
Accepted Dec 22, 202 \\
\hline Keywords: \\
Backstepping control \\
DFIG \\
Lyapunov stability \\
MPPT \\
Wind turbine
\end{tabular}

Article Info

Article history:

Received Jul 15, 2020

Revised Dec 12, 2020

Accepted Dec 22, 2020

Wind turbine

\begin{abstract}
This paper describes a MPPT control of the stator powers of a DFIG operating within a wind energy system using the backstepping control technique. The objective of this work consists of providing a robust control to the rotor-side converter allowing the stator active power to be regulated at the maximum power extracted from the wind turbine, as well as maintaining the stator reactive power at zero to maintain the power factor at unity, under various conditions. We have used the Matlab/Simulink platform to model the wind system based on a $7.5 \mathrm{~kW}$ DFIG and to implement the MPPT control algorithm in a first step, then we have implemented the field-oriented control and the backstepping controller in a second step. The simulation results obtained were very satisfactory with a fast transient response and neglected power ripples. They furthermore confirmed the high robustness of the approach used in dealing with the variation of the internal parameters of the machine.
\end{abstract}

This is an open access article under the CC BY-SA license.

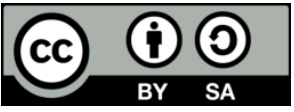

\section{Corresponding Author:}

Yahya Dbaghi

Department of Electrical Engineering

Ibn Zohr University

Ecole Supérieure de Technologie d'Agadir, B.P 33/S, Agadir 80000, Morocco

Email: yahya.dbaghi@edu.uiz.ac.ma

\section{INTRODUCTION}

The investigated wind power system consists of a wind turbine driven by the DFIG shaft via a gearbox as shown in Figure 1. The generator's stator is wired straight into the electrical grid while its rotor dissipates or absorbs its power into the electrical grid through a back-to-back converter, which is composed of an AC/DC converter on the rotor side, a DC link capacitor on the DC bus side, and a DC/AC converter on the grid side. This configuration allows the rotor speed to be adjustable according to the wind speed [1-3].

Variable speed allows the wind turbine to operate over a wider range of wind speeds and to extract the maximum possible power for each wind speed. Compared to some synchronous machines, which use converters traversed by the entire rated power, DFIG's converters are sized to allow only $25 \%$ of the rated power to pass through [4]. They are therefore less cumbersome and less expensive [5, 6].

The research work on the control of the DFIG is almost all based on the field oriented control. This technique which makes the DFIG similar to the DC machine through the separation of the rotor and stator fluxes provides the basis for the implementation of the control methods [7]. In the recent years, the shift towards non-linear control methods by researchers has reached an interesting place in the control scope of converters in systems with sustainable energy, precisely in photovoltaics and wind turbines. Their robustness against disturbances and their ability to withstand non-linear systems renders these control methods an 
efficient tool that satisfies the requirements demanded and offers solutions to issues experienced by the linear PID $[8,9]$.

Although various control methods have recently been proposed in the literature, the linear PI with vector control is still the most famous one, but its drawbacks are numerous, namely its lack of robustness in rejecting internal and external disturbances. Nowadays, researchers have switched to intelligent control strategies such as fuzzy logic, neural networks, and genetic algorithms. While these methods are very robust and efficient, their implementation is not obvious, it requires a high level of expertise on the one hand and they require very fast and powerful calculation processors on the other hand. Lyapunov's stability based nonlinear control methods such as SMC and backstepping remain a good compromise that is easily implementable, robust and offers high satisfaction. These methods have already been proposed by researchers as an application in the control of DFIG-based wind energy systems. In [10] Zamzoum et al. have proposed the technical adaptive sliding mode as a control solution, its results showed that the use of high order sliding mode control offers robustness against variations of internal machine parameters with fast transient response. The backstepping control of the DFIG which was treated by Mensou et al. in [11] also has showed a great robustness against external disturbances as well as offering a very fast response time.

In this paper a backstepping control has been proposed in order to control the rotor-side converter to ensure a smooth regulation of the DFIG stator active power to follow the variation of the maximum power extracted by the turbine. And with the aim of validating the robustness of this control technique we have tested its behaviour under the variation of the internal parameters of the DFIG. This paper is organized as follows: Section 2 deals with wind turbine modeling and the MPPT algorithm. The modeling of the DFIG with field oriented control is presented in section 3. Section 4 describes the design of the backstepping controller. Section 5 is reserved for the presentation and discussion of the simulation results, and the last section gives a conclusion of this work.

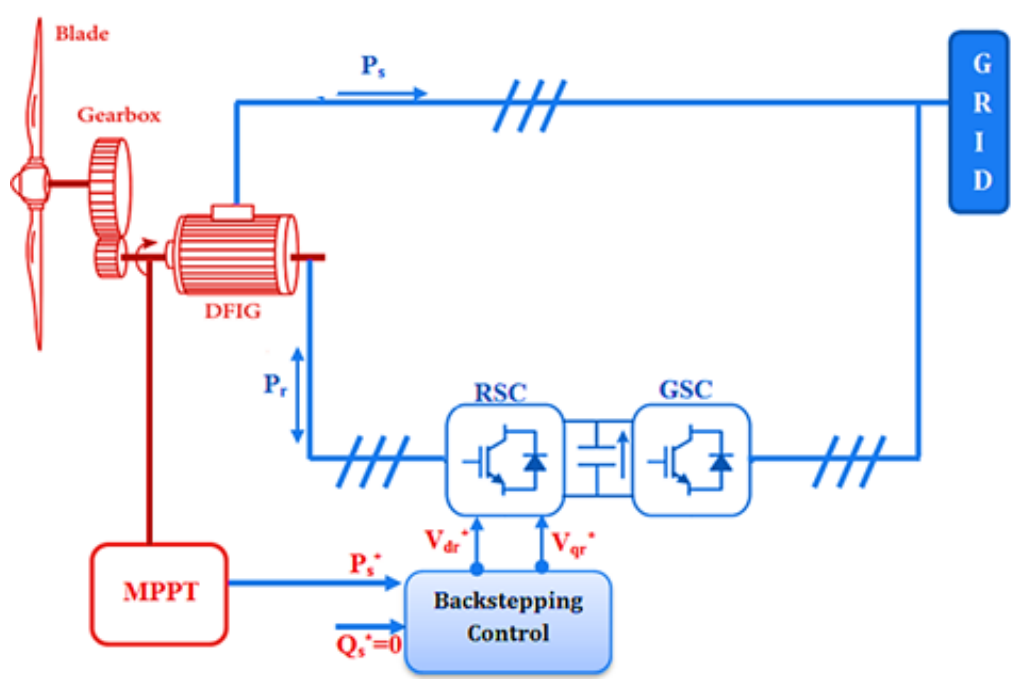

Figure 1. Studied wind turbine system

\section{MODELING OF WIND TURBINE AND MPPT ALGORITHM}

The power generated by the wind turbine is defined by the formula (1) [12]:

$$
\mathrm{P}_{\mathrm{aer}}=\mathrm{C}_{\mathrm{p}}(\lambda, \beta) \cdot \frac{\rho \cdot S \cdot \mathrm{V}^{3}}{2}=\frac{1}{2} \mathrm{C}_{\mathrm{p}}(\lambda, \beta) \cdot \rho \cdot \pi \cdot \mathrm{R}^{2} \cdot \mathrm{V}^{3}
$$

where $\rho$ is the air density, $\mathrm{S}$ is the surface swept by the turbine, $\mathrm{V}$ is the wind speed, $\beta$ is the angle of the orientation of the blades.

$\lambda$ is the speed ratio defined by (2) [13] :

$$
\lambda=\frac{\mathrm{R} \cdot \Omega_{\mathrm{t}}}{\mathrm{V}}
$$

where $\Omega_{\mathrm{t}}$ is the angular velocity of the turbine shaft. 
$\operatorname{Cp}(\lambda, \beta)$ is the power coefficient and refers to the efficiency of the wind turbine in terms of energy conversion, which is expressed (3) [14] :

$$
\left\{\begin{array}{c}
C_{p}(\lambda, \beta)=C_{1}\left(C_{2} \times A-C_{3} \beta-C_{4}\right) e^{-C_{5} \times A}+C_{6} \lambda \\
A=\frac{1}{\lambda+0.08 \beta}-\frac{0.035}{\beta^{3}+1}
\end{array}\right.
$$

with $\mathrm{C}_{1}=0.5109, \mathrm{C}_{2}=116, \mathrm{C}_{3}=0.4, \mathrm{C}_{4}=5, \mathrm{C}_{5}=21, \mathrm{C}_{6}=0.0068$.

The power coefficient evolutions as a function of the speed ratio $\lambda$ and the beta $\beta$ are illustrated in Figure 2. It is shown on this figure that for operation in MPPT mode with $\beta=0^{\circ}$, the optimum speed ratio is $\lambda \mathrm{opt}=8.1$ for $\mathrm{Cpmax}=0.48$.

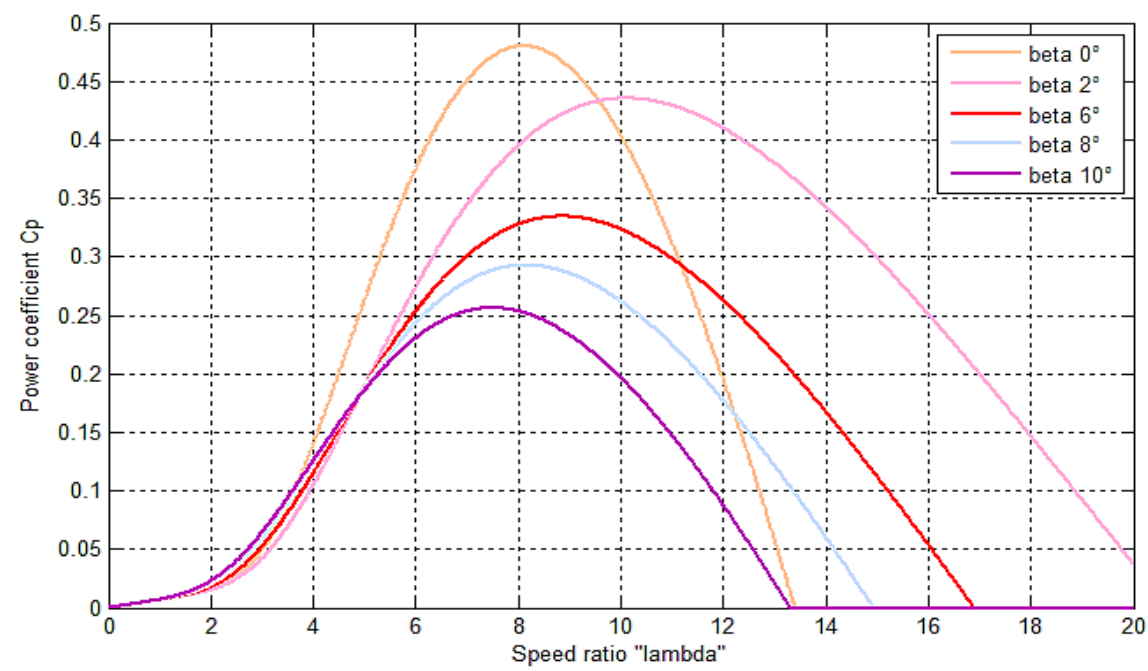

Figure 2. Power coefficient $\mathrm{Cp}$

The expression of the aerodynamic torque is (4):

$$
\text { Taer }=\frac{P_{\mathrm{aer}}}{\Omega_{\mathrm{t}}}=\frac{1}{2} \mathrm{C}_{\mathrm{p}}(\lambda, \beta) \cdot \frac{\rho \cdot \pi \cdot \mathrm{R}^{2} \cdot \mathrm{V}^{3}}{\Omega_{\mathrm{t}}}
$$

The rotary speed and torque at the generator shaft are defined as (5) [15]:

$$
\left\{\begin{array}{c}
\Omega_{\mathrm{mec}}=\mathrm{G} . \Omega_{\mathrm{t}} \\
\mathrm{Tg}=\frac{\mathrm{T}_{\mathrm{aer}}}{\mathrm{G}}
\end{array}\right.
$$

where

$\Omega_{\text {mec }}$ : mechanical speed of the generator.

$\mathrm{T}_{\mathrm{g}}$ : The generator torque.

Applying Newton's second law of motion to the generator shaft gives:

$$
\left\{\begin{array}{c}
T_{g}-T_{e m}-f \Omega=J \frac{d \Omega_{m e c}}{d t} \\
J=\frac{J_{t}}{G}+J_{g}
\end{array}\right.
$$

with:

$\mathrm{J}, \mathrm{J}_{\mathrm{g}}, \mathrm{J}_{\mathrm{t}}$ : the total inertia, the generator inertia, and the turbine inertia.

f: Damping coefficient.

$\mathrm{T}_{\mathrm{em}}$ : the electromagnetic torque of the generator.

We can eventually express the optimum electromagnetic torque corresponding to the maximum power as shown in (7) [16]: 


$$
\mathrm{T}_{\mathrm{emopt}}=\frac{\mathrm{C}_{\mathrm{pmax}}(\lambda, \beta)}{\lambda_{\mathrm{opt}}^{3}} \times \frac{\rho \cdot \pi \cdot \mathrm{R}^{5}}{2} \times \frac{\Omega_{\mathrm{mec}}^{2}}{\mathrm{G}^{3}}
$$

The block diagram of the wind turbine with the MPPT algorithm is shown in Figure 3.

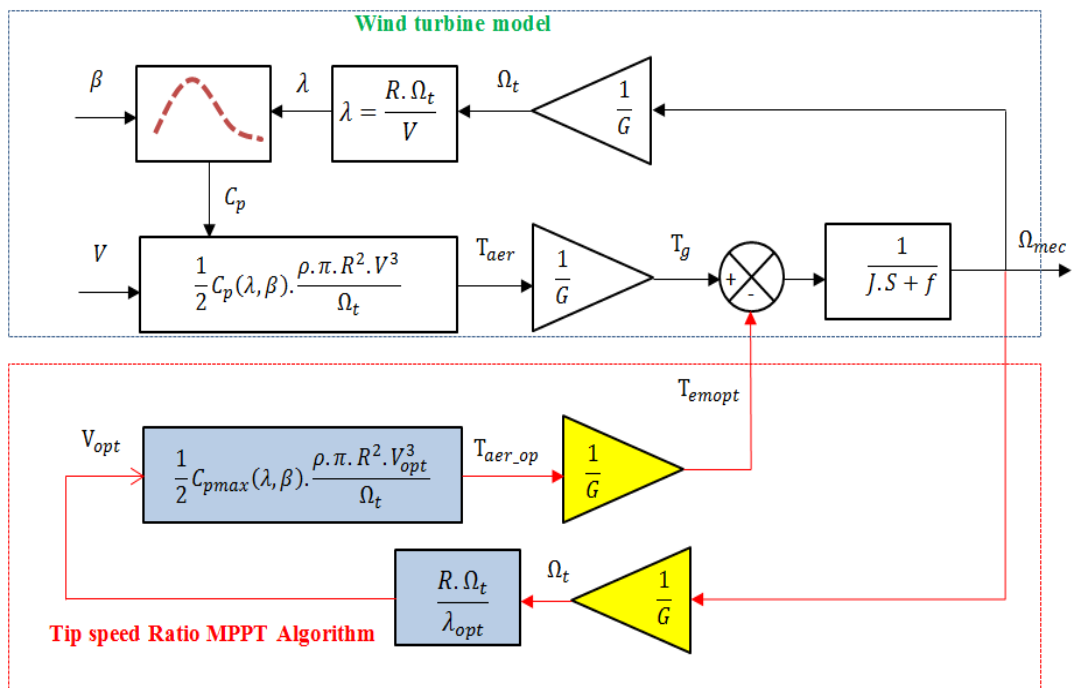

Figure 3. Block diagram of the wind turbine system with MPPT

\section{MODELING AND VECTOR CONTROL OF THE DFIG}

DFIG's rotor and stator voltages equations in the park frame are expressed as (8) [17]:

$$
\left\{\begin{array}{l}
\mathrm{V}_{\mathrm{ds}}=\mathrm{R}_{\mathrm{s}} \mathrm{I}_{\mathrm{ds}}+\frac{\mathrm{d}}{\mathrm{dt}} \varphi_{\mathrm{ds}}-\omega_{\mathrm{s}} \varphi_{\mathrm{qs}} \\
\mathrm{V}_{\mathrm{qs}}=\mathrm{R}_{\mathrm{s}} \mathrm{I}_{\mathrm{qs}}+\frac{\mathrm{d}}{\mathrm{dt}} \varphi_{\mathrm{qs}}+\omega_{\mathrm{s}} \varphi_{\mathrm{ds}} \\
\mathrm{V}_{\mathrm{dr}}=\mathrm{R}_{\mathrm{r}} \mathrm{I}_{\mathrm{dr}}+\frac{\mathrm{d}}{\mathrm{dt}} \varphi_{\mathrm{dr}}-\omega_{\mathrm{r}} \varphi_{\mathrm{qr}} \\
\mathrm{V}_{\mathrm{qr}}=\mathrm{R}_{\mathrm{r}} \mathrm{I}_{\mathrm{qr}}+\frac{\mathrm{d}}{\mathrm{dt}} \varphi_{\mathrm{qr}}+\omega_{\mathrm{r}} \varphi_{\mathrm{dr}}
\end{array}\right.
$$

where $\mathrm{Rr}$ and $\mathrm{Rs}$ are respectively the rotor and stator resistances per phase.

Rotor and stator flux are defined as (9) [18]:

$$
\left\{\begin{array}{l}
\varphi_{\mathrm{ds}}=\mathrm{L}_{\mathrm{s}} \mathrm{I}_{\mathrm{ds}}+\mathrm{MI}_{\mathrm{dr}} \\
\varphi_{\mathrm{qs}}=\mathrm{L}_{\mathrm{s}} \mathrm{I}_{\mathrm{qs}}+\mathrm{MI}_{\mathrm{qr}} \\
\varphi_{\mathrm{dr}}=\mathrm{L}_{\mathrm{r}} \mathrm{I}_{\mathrm{dr}}+\mathrm{MI}_{\mathrm{ds}} \\
\varphi_{\mathrm{qr}}=\mathrm{L}_{\mathrm{r}} \mathrm{I}_{\mathrm{qr}}+\mathrm{MI}_{\mathrm{qs}}
\end{array}\right.
$$

where $L_{r}, L_{s}$ are respectively the rotor and stator inductances. $M$ is the machine mutual inductance. $I_{d r}, I_{q r}, I_{d s}$, $\mathrm{I}_{\mathrm{qs}}$, are respectively the $(\mathrm{d}, \mathrm{q})$ rotor and stator currents.

The stator active and reactive powers are defined by (10):

$$
\left\{\begin{array}{l}
\mathrm{P}_{\mathrm{s}}=\mathrm{V}_{\mathrm{ds}} \mathrm{I}_{\mathrm{ds}}+\mathrm{V}_{\mathrm{qs}} \mathrm{I}_{\mathrm{qs}} \\
\mathrm{Q}_{\mathrm{s}}=\mathrm{V}_{\mathrm{qs}} \mathrm{I}_{\mathrm{ds}}-\mathrm{V}_{\mathrm{ds}} \mathrm{I}_{\mathrm{qs}}
\end{array}\right.
$$

Electromagnetic torque is expressed as [19]:

$$
\mathrm{T}_{\mathrm{em}}=\frac{\mathrm{pM}}{\mathrm{L}_{\mathrm{s}}}\left(\mathrm{I}_{\mathrm{dr}} \varphi_{\mathrm{qs}}-\mathrm{I}_{\mathrm{qr}} \varphi_{\mathrm{ds}}\right)
$$

where $\mathrm{p}$ is the pair pole number: 
By aligning the d-axis in the direction of the stator flux [20], we obtain:

$$
\varphi_{\mathrm{ds}}=\varphi_{\mathrm{s}}, \varphi_{\mathrm{qs}}=0
$$

As a consequence, the stator flux expressions become:

$$
\left\{\begin{array}{c}
\varphi_{\mathrm{s}}=\mathrm{L}_{\mathrm{s}} \mathrm{I}_{\mathrm{ds}}+\mathrm{MI}_{\mathrm{dr}} \\
0=\mathrm{L}_{\mathrm{s}} \mathrm{I}_{\mathrm{qs}}+\mathrm{MI}_{\mathrm{qr}}
\end{array}\right.
$$

The stator resistance is negligible because of its small value. In this sense, the stator voltages can be described as (14):

$$
\left\{\begin{array}{c}
\mathrm{V}_{\mathrm{ds}}=0 \\
\mathrm{~V}_{\mathrm{qs}}=\mathrm{V}_{\mathrm{s}}=\omega_{\mathrm{s}} \varphi_{\mathrm{s}}
\end{array}\right.
$$

From (13) and (14) the stator currents can be expressed as:

$$
\left\{\begin{array}{c}
\mathrm{I}_{\mathrm{ds}}=\frac{\varphi_{\mathrm{s}}}{\mathrm{L}_{\mathrm{s}}}-\frac{\mathrm{M}}{\mathrm{L}_{\mathrm{s}}} \mathrm{I}_{\mathrm{dr}} \\
\mathrm{I}_{\mathrm{qs}}=-\frac{\mathrm{M}}{\mathrm{L}_{\mathrm{s}}} \mathrm{I}_{\mathrm{qr}}
\end{array}\right.
$$

By combining (10), (14) and (15) the stator active and reactive powers become:

$$
\left\{\begin{array}{c}
P_{s}=-V_{s} \frac{M}{L_{s}} I_{q r} \\
Q_{s}=\frac{V_{s}^{2}}{\omega_{s} L_{s}}-V_{s} \frac{M}{L_{s}} I_{d r}
\end{array}\right.
$$

Hence, we can express the rotor voltages $(\mathrm{d}, \mathrm{q})$ in $(17)$ :

$$
\left\{\begin{array}{l}
\mathrm{V}_{\mathrm{dr}}=\mathrm{R}_{\mathrm{r}} \mathrm{I}_{\mathrm{dr}}+\left(\mathrm{L}_{\mathrm{r}}-\frac{\mathrm{M}^{2}}{\mathrm{~L}_{\mathrm{s}}}\right) \frac{\mathrm{dI}_{\mathrm{dr}}}{\mathrm{dt}}+\mathrm{e}_{\mathrm{q}} \\
\mathrm{V}_{\mathrm{qr}}=\mathrm{R}_{\mathrm{r}} \mathrm{I}_{\mathrm{qr}}+\left(\mathrm{L}_{\mathrm{r}}-\frac{\mathrm{M}^{2}}{\mathrm{~L}_{\mathrm{s}}}\right) \frac{\mathrm{dI}_{\mathrm{qr}}}{\mathrm{dt}}+\mathrm{e}_{\mathrm{d}}
\end{array}\right.
$$

In which the coupling voltages $\mathrm{e}_{\mathrm{d}}$ and $\mathrm{e}_{\mathrm{q}}$ are expressed as:

$$
\left\{\begin{array}{l}
e_{q}=-\omega_{r}\left(L_{r}-\frac{M^{2}}{L_{s}}\right) I_{q r} \\
e_{d}=\omega_{r}\left(L_{r}-\frac{M^{2}}{L_{s}}\right) I_{d r}+\frac{g V_{s}}{L_{s}}
\end{array}\right.
$$

where $\mathrm{g}$ is the slip.

\section{BACKSTEPPING CONTROL IN THE LOOP OF INDIRECT FIELD ORIENTED CONTROL}

The fundamental idea of backstepping is to synthesize the control law in a recursive way, at each step a system state is stabilized, assuming the next state as a virtual control. The objective of the method is to design a control law that brings the system to a desired state, which is generally a stable closed-loop steady state [21]. These can be achieved by using Lyapunov's functions which ensure stepwise stability [22].

- Step 1 Active and reactive power control

The active and reactive power errors are defined as:

$$
\left\{\begin{array}{l}
z_{1}=P_{s}^{*}-P_{s} \\
z_{3}=Q_{s}^{*}-Q_{s}
\end{array}\right.
$$

By deriving the error we obtain:

$\left\{\begin{array}{l}\dot{\mathrm{z}}_{1}=\dot{\mathrm{P}}_{\mathrm{s}}^{*}-\dot{\mathrm{P}}_{\mathrm{s}} \\ \dot{\mathrm{z}}_{3}=\dot{\mathrm{Q}}_{\mathrm{s}}^{*}-\dot{\mathrm{Q}}_{\mathrm{s}}\end{array}\right.$ 
The first Lyapunov candidate function is:

$$
\mathrm{V}_{1}=\frac{1}{2} \mathrm{z}_{1}^{2}+\frac{1}{2} \mathrm{z}_{3}^{2}
$$

The derivative of the function $V_{1}$ is expressed as:

$$
\dot{\mathrm{V}}_{1}=\mathrm{z}_{1} \dot{\mathrm{z}}_{1}+\mathrm{z}_{3} \dot{\mathrm{z}}_{3}
$$

Therefore $\mathrm{V}_{1}$ can be expressed as:

$$
\dot{\mathrm{V}}_{1}=-\mathrm{C}_{1} \mathrm{z}_{1}^{2}-\mathrm{C}_{3} \mathrm{z}_{3}^{2}
$$

$C_{1}$ and $C_{3}$ are positive constants ensuring the Lyapunov stability condition [23-24]. The derivative of the power errors becomes:

$$
\left\{\begin{array}{l}
\dot{\mathrm{z}}_{1}=\dot{\mathrm{P}}_{\mathrm{s}}^{*}+\frac{\mathrm{V}_{\mathrm{s}} \mathrm{M}}{\mathrm{L}_{\mathrm{s}}} \dot{\mathrm{I}}_{\mathrm{qr}}=-\mathrm{C}_{1} \mathrm{z}_{1} \\
\dot{\mathrm{z}}_{3}=\dot{\mathrm{Q}}_{\mathrm{s}}^{*}+\frac{\mathrm{V}_{\mathrm{s}} \mathrm{M}}{\mathrm{L}_{\mathrm{s}}} \dot{\mathrm{I}}_{\mathrm{dr}}=-\mathrm{C}_{3} \mathrm{z}_{3}
\end{array}\right.
$$

From (24) rotor currents references are expressed as (25):

$$
\left\{\begin{array}{l}
\dot{\mathrm{I}}_{\mathrm{dr}}^{*}=\frac{\mathrm{L}_{\mathrm{s}}}{\mathrm{V}_{\mathrm{s}} \mathrm{M}}\left(-\dot{\mathrm{Q}}_{\mathrm{s}}^{*}-\mathrm{C}_{3} \mathrm{z}_{3}\right) \\
\dot{\mathrm{I}}_{\mathrm{qr}}^{*}=\frac{\mathrm{L}_{\mathrm{s}}}{\mathrm{V}_{\mathrm{s}} \mathrm{M}}\left(-\dot{\mathrm{P}}_{\mathrm{s}}^{*}-\mathrm{C}_{1} \mathrm{z}_{1}\right)
\end{array}\right.
$$

- Step 2 Rotor currents control

The rotor currents errors are defined as:

$$
\left\{\begin{array}{l}
\mathrm{z}_{2}=\mathrm{I}_{\mathrm{qr}}^{*}-\mathrm{I}_{\mathrm{qr}} \\
\mathrm{z}_{4}=\mathrm{I}_{\mathrm{dr}}^{*}-\mathrm{I}_{\mathrm{dr}}
\end{array}\right.
$$

The derivative of the rotor currents errors is:

$$
\left\{\begin{array}{l}
\dot{\mathrm{z}}_{2}=\dot{\mathrm{I}}_{\mathrm{qr}}^{*}-\dot{\mathrm{I}}_{\mathrm{qr}} \\
\dot{\mathrm{z}}_{4}=\dot{\mathrm{I}}_{\mathrm{dr}}^{*}-\dot{\mathrm{I}}_{\mathrm{dr}}
\end{array}\right.
$$

with:

$$
\left\{\begin{array}{l}
\dot{\mathrm{I}}_{\mathrm{dr}}=\frac{1}{\mathrm{~L}_{\mathrm{r}} \sigma}\left(\mathrm{V}_{\mathrm{dr}}-\mathrm{R}_{\mathrm{r}} \mathrm{I}_{\mathrm{dr}}-\mathrm{e}_{\mathrm{q}}\right) \\
\dot{\mathrm{I}}_{\mathrm{qr}}=\frac{1}{\mathrm{~L}_{\mathrm{r}} \sigma}\left(\mathrm{V}_{\mathrm{qr}}-\mathrm{R}_{\mathrm{r}} \mathrm{I}_{\mathrm{qr}}-\mathrm{e}_{\mathrm{d}}\right)
\end{array}\right.
$$

The second Lyapunov function chosen is defined as:

$$
\mathrm{V}_{2}=\frac{1}{2}\left(\mathrm{z}_{1}^{2}+\mathrm{z}_{2}^{2}+\mathrm{z}_{3}^{2}+\mathrm{z}_{4}^{2}\right)
$$

The derivative of $\mathrm{V}_{2}$ is defined as (30):

$$
\dot{\mathrm{V}}_{2}=\mathrm{z}_{1} \dot{\mathrm{z}}_{1}+\mathrm{z}_{2} \dot{\mathrm{z}}_{2}+\mathrm{z}_{3} \dot{\mathrm{z}}_{3}+\mathrm{z}_{4} \dot{\mathrm{z}}_{4}
$$

We can rewrite (30) is being as:

$$
\dot{\mathrm{V}}_{2}=-\mathrm{C}_{1} \mathrm{z}_{1}^{2}-\mathrm{C}_{2} \mathrm{z}_{2}^{2}-\mathrm{C}_{3} \mathrm{z}_{3}^{2}-\mathrm{C}_{4} \mathrm{z}_{4}^{2}
$$

$\mathrm{C}_{2}$ and $\mathrm{C}_{4}$ are positive constants ensuring the Lyapunov stability condition. 


$$
\left\{\begin{array}{l}
\dot{\mathrm{z}}_{2}=\frac{\mathrm{L}_{\mathrm{s}}}{\mathrm{V}_{\mathrm{s}} \mathrm{M}}\left(-\dot{\mathrm{P}}_{\mathrm{s}}^{*}-\mathrm{C}_{1} \mathrm{z}_{1}\right)-\frac{1}{\mathrm{~L}_{\mathrm{r}} \sigma}\left(\mathrm{V}_{\mathrm{qr}}-\mathrm{R}_{\mathrm{r}} \mathrm{I}_{\mathrm{qr}}\right)=-\mathrm{C}_{2} \mathrm{z}_{2} \\
\dot{\mathrm{z}}_{4}=\frac{\mathrm{L}_{\mathrm{s}}}{\mathrm{V}_{\mathrm{s}} \mathrm{M}}\left(-\dot{\mathrm{Q}}_{\mathrm{s}}^{*}-\mathrm{C}_{3} \mathrm{z}_{3}\right)-\frac{1}{\mathrm{~L}_{\mathrm{r}} \sigma}\left(\mathrm{V}_{\mathrm{dr}}-\mathrm{R}_{\mathrm{r}} \mathrm{I}_{\mathrm{dr}}\right)=-\mathrm{C}_{4} \mathrm{z}_{4}
\end{array}\right.
$$

with $\sigma=\left(1-\frac{\mathrm{M}^{2}}{\mathrm{~L}_{\mathrm{r}} \mathrm{L}_{\mathrm{s}}}\right)$.

Then the references rotor voltages are given by:

$$
\begin{aligned}
& \mathrm{V}_{\mathrm{dr}}{ }^{*}=\mathrm{L}_{\mathrm{r}} \sigma\left(\frac{\mathrm{L}_{\mathrm{S}}}{\mathrm{V}_{\mathrm{s}} \mathrm{M}}\left(-\dot{\mathrm{Q}}_{\mathrm{s}}^{*}-\mathrm{C}_{3} \mathrm{z}_{3}\right)+\frac{\mathrm{R}_{\mathrm{r}}}{\mathrm{L}_{\mathrm{r}} \sigma} \mathrm{I}_{\mathrm{dr}}+\mathrm{K}_{4} \mathrm{z}_{4}\right) \\
& \mathrm{V}_{\mathrm{qr}}{ }^{*}=\mathrm{L}_{\mathrm{r}} \sigma\left(\frac{\mathrm{L}_{\mathrm{s}}}{\mathrm{V}_{\mathrm{s}} \mathrm{M}}\left(-\dot{\mathrm{P}}_{\mathrm{s}}^{*}-\mathrm{C}_{1} \mathrm{z}_{1}\right)+\frac{\mathrm{R}_{\mathrm{r}}}{\mathrm{L}_{\mathrm{r}} \sigma} \mathrm{I}_{\mathrm{qr}}+\mathrm{K}_{2} \mathrm{z}_{2}\right)
\end{aligned}
$$

The Figure 4 illustrates the indirect flux oriented control of DFIG using the backstepping method. The diagram contains the calculation blocks for the desired rotor currents and voltages, the PARK transformation blocks, a PWM inverter on the rotor side, and the model of the DFIG in the PARK frame dq.

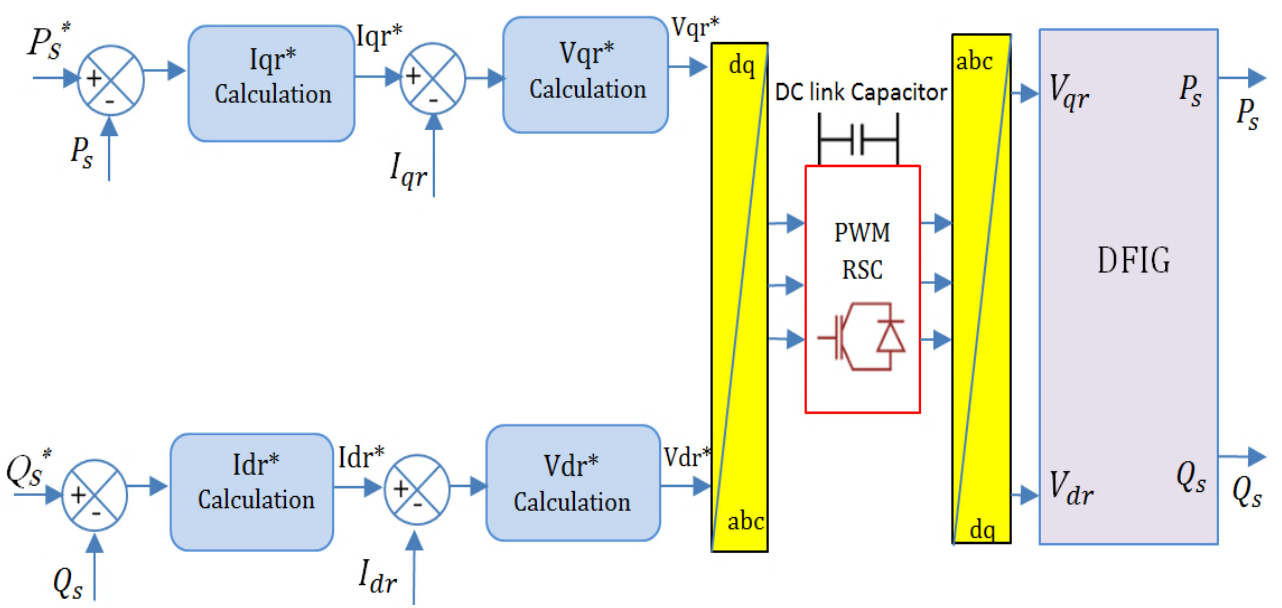

Figure 4. Block diagram of IFOC backstepping control

\section{SIMULATION RESULTS AND DISCUSSION}

\subsection{Normal test simulation}

This part presents the results of the simulation of the wind turbine assembly with DFIG. We have applied a wind profile to the turbine illustrated by the Figure 5. Figure 6 presents the mechanical speed response of the DFIG.

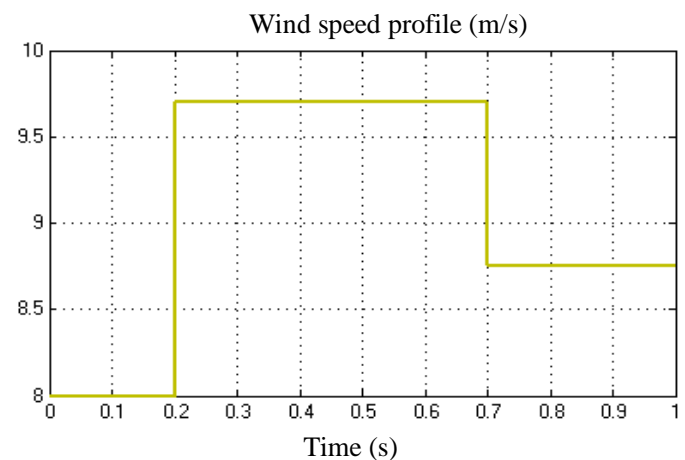

Figure 5. Wind speed

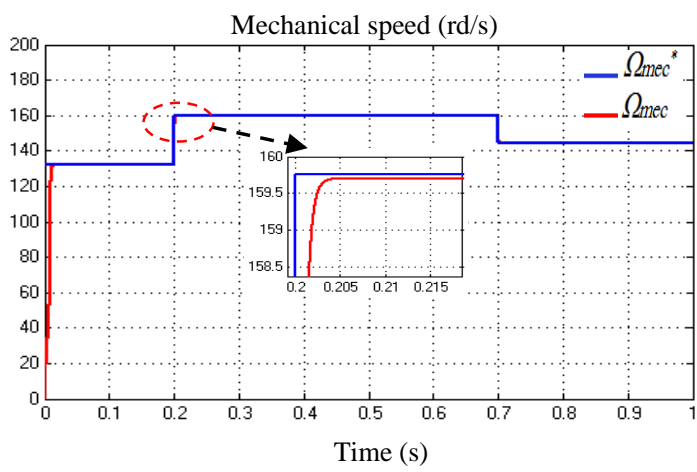

Figure 6. Mechanical speed response 
It can be clearly seen on the figure that the DFIG angular velocity follows perfectly its reference speed image of the MPPT, as validated by maintaining of the power coefficient $\mathrm{Cp}$ around its optimal value of 0.48 as shown in Figure 7. The maximum power produced by the wind turbine is therefore the reference applied to the active stator power control loop of the DFIG, the simulation results as presented in Figure 8 show a perfect tracking of the MPPT power by the DFIG while the response time is tr5\%=0.4 (ms) and some neglected power oscillations, on the same figure one can see the variation of the rotor active power which varies according to the operating mode of the machine (hypo-synchronous or hyper-synchronous). Figure 9 also shows a very satisfactory regulation of the reactive stator power at a zero value, this being confirmed by Figure 10 which shows that as a result the power factor is maintained at unity. The coupling terms presented in (17) are perfectly compensated and this is of obvious benefit by the use of indirect flux control. In Figure 11 the variations of the stator current injected into the electrical grid are shown, they are smooth and present a very low THD $\%=0.75$ according to the FFT analysis Figure 12 .

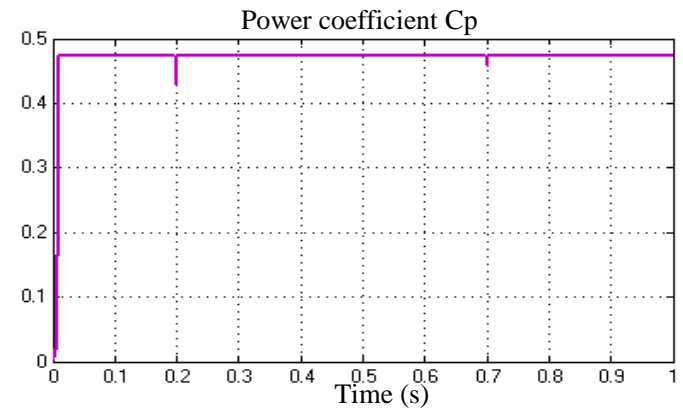

Figure 7. Power coefficient response

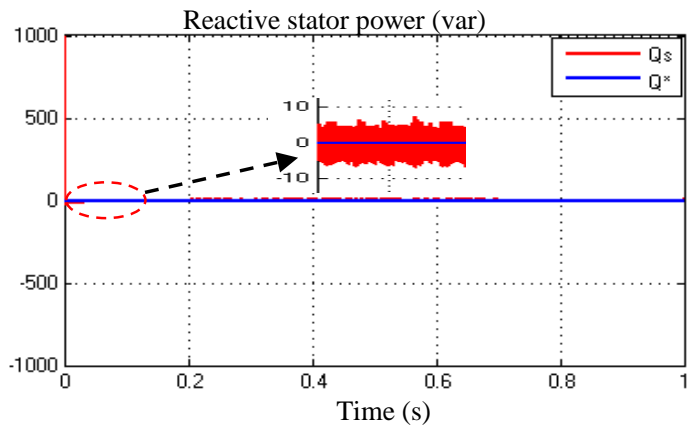

Figure 9. Reactive stator power response

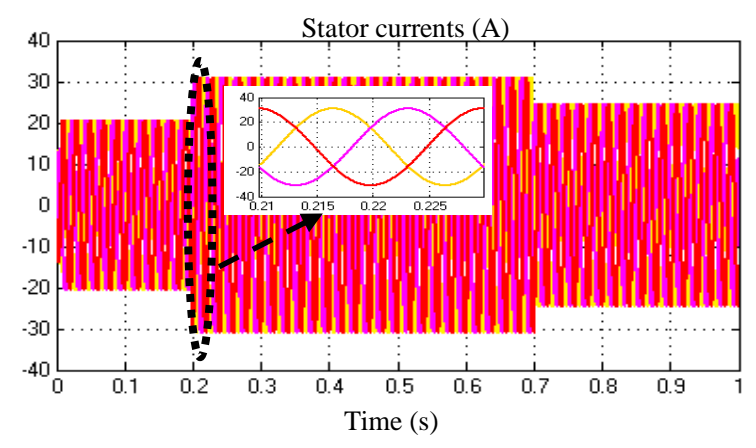

Figure 11. Stator currents response

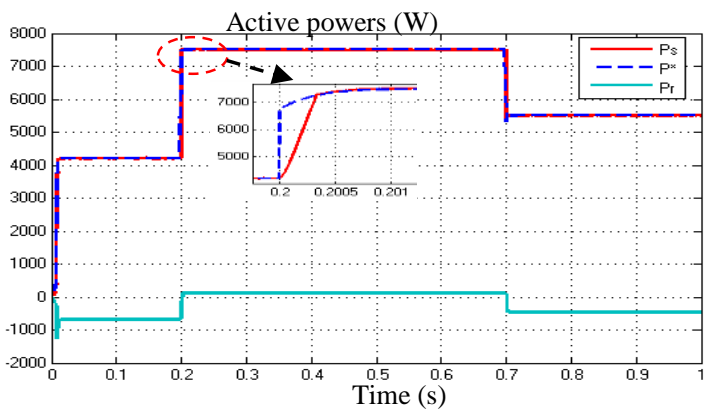

Figure 8. Active stator and rotor power response

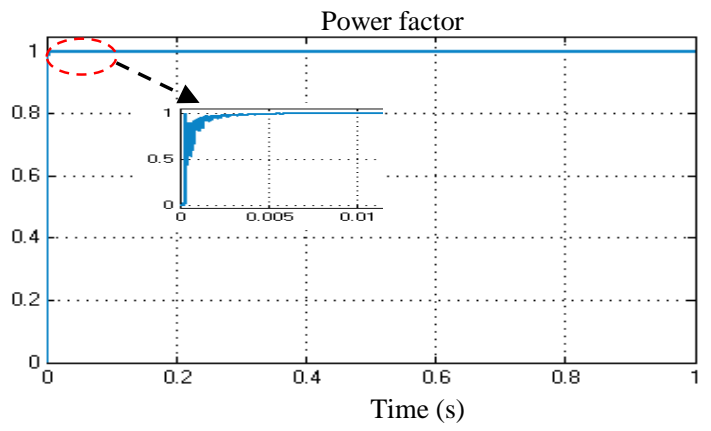

Figure 10. Power factor response

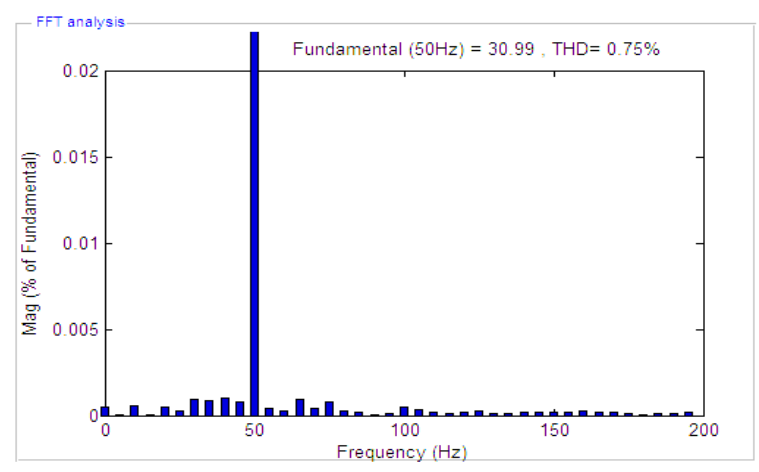

Figure 12. FFT analysis of stator currents 


\subsection{Robustness test simulation}

In order to test the robustness of the Backstepping controller against unexpected variations in the internal parameters of the DFIG, caused by an increase in temperature or other events. We have elaborated a robustness test in which the rotor resistance and inductance values are increased by $50 \%$ :

$$
\left\{\begin{array}{l}
\mathrm{L}_{\mathrm{r}}{ }_{\mathrm{r}}=\mathrm{L}_{\mathrm{r}} \times 1.5 \\
\mathrm{R}_{\mathrm{r}}{ }^{\prime}=\mathrm{R}_{\mathrm{r}} \times 1.5
\end{array}\right.
$$

Figures 13-15 illustrate the simulation results. It is immediately observed that the regulations have been fully ensured both for the active and reactive power but there is some slight degradation of the performances obtained previously. At the level of active power we have an increase in response time to $\operatorname{tr} 5 \%=1.7(\mathrm{~ms})$ with an overshoot of $100(\mathrm{~W})$ which remains very negligible for a few $(\mathrm{ms})$. For the reactive power we also have an overshoot of -100 (var) during the first $40 \mathrm{~ms}$. These results confirm that the backstepping control is highly robust through indirect field oriented control. It offers a perfect decoupling between the $\mathrm{d}$ and $\mathrm{q}$ axes, a much reduced response time and minimal power oscillations in the face of disturbances resulting from variations in the internal DFIG's parameters.

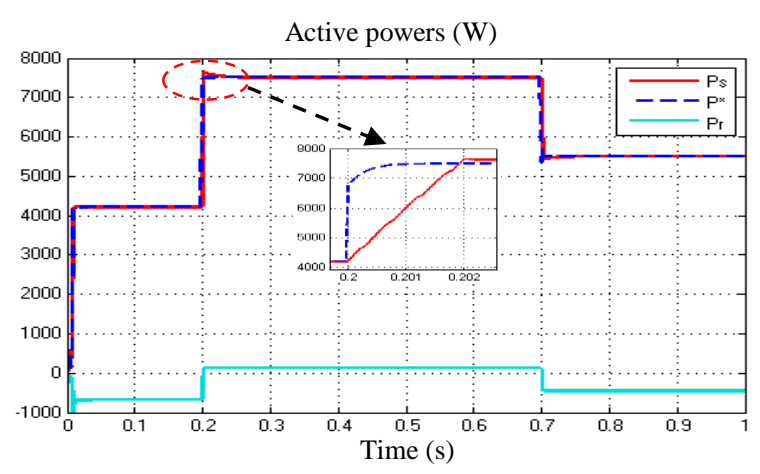

Figure 13. Active stator and rotor power response in robustness test

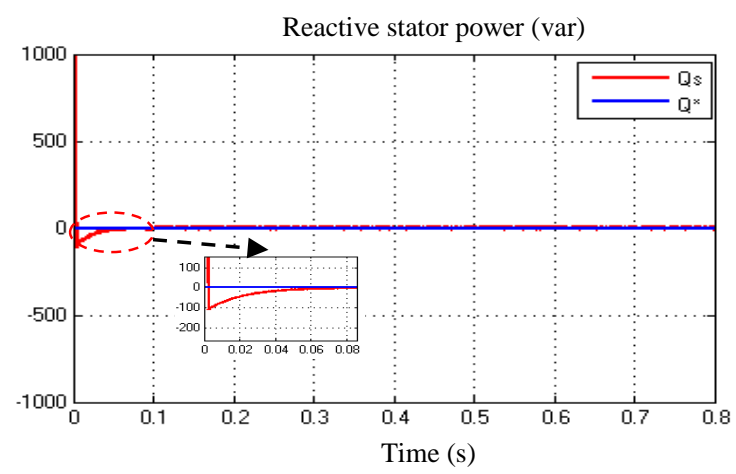

Figure 14. Reactive stator power response in robustness test

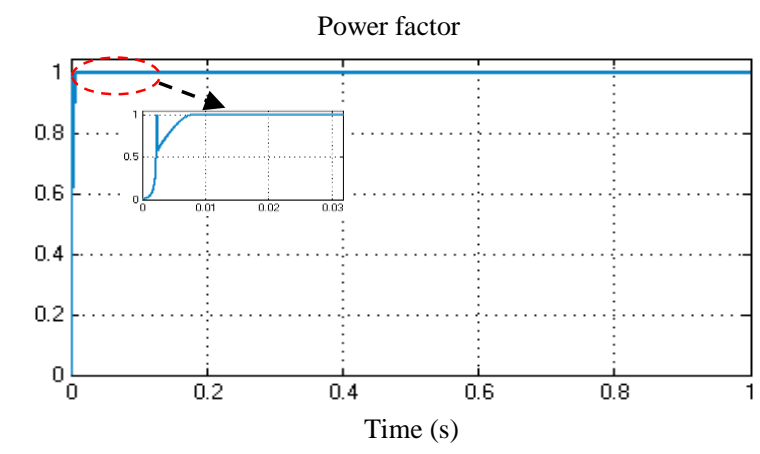

Figure 15. Reactive stator power response in robustness test

\section{CONCLUSION}

This work presents the modeling and the control of a DFIG-based wind energy system using backstepping technique under variable wind speed. The maximum power point tracking was achieved by using the tip speed ratio algorithm. The results of the simulation of the indirect field oriented control with backstepping controller showed a high stability of the system as well as a very fast response, with a very low total harmonic distortion of the stator currents injected into the power grid, even with the variation of the internal parameters of the DFIG. However, these results confirm the efficiency of this non-linear backstepping control which is easy to implement and gives sometimes better results than the use of the new control based on artificial intelligence such as fuzzy logic or neural network control. 


\section{APPENDIX} turbine system.

The following Table 1 presents the nominal values of the different parameters of the studied wind

Table 1. DFIG and wind turbine parameters [25]

\begin{tabular}{cccc}
\hline Wind turbine parameters & Values & DFIG parameters & Values \\
\hline Rated power & $7.5 \mathrm{KW}$ & Rated power & $7.5 \mathrm{KW}$ \\
Damping coefficient & $0,024 \mathrm{~N} \cdot \mathrm{m} . \mathrm{s} . \mathrm{rad}-1$ & Rated stator voltage & $220 / 380 \mathrm{~V}$ \\
Air density & $1.225 \mathrm{Kg} \cdot \mathrm{m}-3$ & Number of pole pairs & $\mathrm{p}=2$ \\
Blade radius & $3 \mathrm{~m}$ & Rotor resistance & $\mathrm{Rr}=0.19 \Omega$ \\
Mechanical speed multiplier & 5.4 & Stator resistance & $\mathrm{Rs}=0.455 \Omega$ \\
Moment of inertia & $0,042 \mathrm{Kg} \cdot \mathrm{m}-1$ & Stator inductance & $\mathrm{Ls}=0.07 \mathrm{H}$ \\
& & Rotor inductance & $\mathrm{Lr}=0.0213 \mathrm{H}$ \\
& & Mutual inductance & $\mathrm{M}=0.034 \mathrm{H}$ \\
\hline
\end{tabular}

\section{REFERENCES}

[1] S. A. Davari, "Predictive rotor control of DFIG supplied with back-back converters for variable speed wind turbine application," 2014 IEEE 23rd International Symposium on Industrial Electronics (ISIE), Istanbul, 2014, pp. 1415-1419.

[2] M. Taoussi, M. Karim, D. Hammoumi, C. E. Bekkali, B. Bossoufi, and N. E. Ouanjli, "Comparative study between backstepping adaptive and field-oriented control of the DFIG applied to wind turbines," 2017 International Conference on Advanced Technologies for Signal and Image Processing (ATSIP), Fez, 2017, pp. 1-6.

[3] S. Labdai, B. Hemici, L. Nezli, N. Bounar, A. Boulkroune, and L. Chrifi-Alaoui, "Robust Control based on Backstepping and adaptive neural network for the DFIG based WECS," 2019 International Conference on Control, Automation and Diagnosis (ICCAD), Grenoble, France, 2019, pp. 1-6.

[4] S. Farhat, R. Alaoui, A. Kahaji, and L. Bouhouch, "Wind Turbine MPPT Strategy with DFIG Vector Control," International Review on Modelling and Simulations (IREMOS), vol. 11, no. 6, p. 406, 2018.

[5] A. Daoud and N. Derbel, "Direct Power Control of DFIG Using Sliding Mode Control Approach," Modeling, Identification and Control Methods in Renewable Energy Systems, pp. 193-204, 2018.

[6] D. Porate, S. P. Gawande, K. B. Porate, R. N. Nagpure, M. A. Waghmare, and S. G. Kadwane, "Performance of PMSG Based Variable Speed WECS with Parallel Back-to-Back Converters Using Separate Zero d-axis Current Control," 2018 IEEE International Conference on Power Electronics, Drives and Energy Systems (PEDES), Chennai, India, 2018, pp. 1-6.

[7] I. Karaoui, M. Maaroufi, and B. Bossoufi, "Robust power control methods for wind turbines using DFIGgenerator," International Journal of Power Electronics and Drive Systems(IJPEDS), vol. 10, pp. 2101-2117, 2019.

[8] J. E. Son, "Adaptive and Robust Controls for Uncertain Linear and Nonlinear Systems," [Gainesville, Fla.]: University of Florida, 2012.

[9] B. Bhalerao and V. V. Khatavkar, "A Literature Review on Modelling and Control of Solar-Wind Hybrid System using PID \& Fuzzy-PID Controller," 2018 International Conference on Recent Innovations in Electrical, Electronics \& Communication Engineering (ICRIEECE), Bhubaneswar, India, 2018, pp. 2416-2421.

[10] O. Zamzoum, Y. El Mourabit, M. Errouha, A. Derouich and A. El Ghzizal, "Active and Reactive Power Control of Wind Turbine based on Doubly Fed Induction Generator using Adaptive Sliding Mode Approach," International Journal of Advanced Computer Science and Applications (IJACSA), vol. 10, no. 2, 2019.

[11] Mensou S., Essadki A., Nasser T., Bououlid I. B, and Ben T. L., "Dspace DS1104 implementation of a robust nonlinear controller applied for DFIG driven by wind turbine," Renewable Energy, vol. 147, pp. 1759-1771, 2020.

[12] E. Elhaji, "Modeling and Control of Wind Turbine to Damp the Power Oscillation," Stability Control and Reliable Performance of Wind Turbines, 2018. Available: 10.5772/intechopen.74835.

[13] I. Idrissi, H. Chafouk, R. El Bachtiri, and M. Khanfara, "Modeling and Simulation of the Variable Speed Wind Turbine Based on a Doubly Fed Induction Generator," Modeling of Turbomachines for Control and Diagnostic Applications, IntechOpen, 2019.

[14] Y. Dbaghi, S. Farhat, and M. Mediouni, "First Order Sliding Mode and Super-twisting Sliding Mode Control of Doubly Fed Induction Generator Driven by Wind Turbine System: A Comparative Study," Journal of Advanced Research in Dynamical and Control Systems, vol. 12, no. 04, pp. 1656-1667, 2020.

[15] B. Bossoufi, M. Karim, A. Lagrioui, M. Taoussi, and A. Derouich, "Observer backstepping control of DFIGGenerators for wind turbines variable-speed,FPGA-based implementation," Renewable Energy, vol. 81, pp. 903-917, 2015.

[16] D. Kumar and K. Chatterjee, "A review of conventional and advanced MPPT algorithms for wind energy systems," Renewable and Sustainable Energy Reviews, vol. 55, pp. 957-970, 2016.

[17] M. Bouderbala, B. Bossoufi, A. Lagrioui, M. Taoussi, H. Aroussi, and Y. Ihedrane, "Direct and indirect vector control of a doubly fed induction generator based in a wind energy conversion system," International Journal of Electrical and Computer Engineering (IJECE), vol. 9, no. 3, pp. 1531-1540, 2019. 
[18] C. Ahlem, B. A, D. I and B. Barkati, "Comparative study of two control strategies proportional integral and fuzzy logic for the control of a doubly fed induction generator dedicated to a wind application," International Journal of Power Electronics and Drive Systems (IJPEDS), vol. 11, no. 1, pp. 263-274, 2020.

[19] Y. Bakou et al., "DTC Control of the DFIG, Application to the Production of Electrical Energy," 2019 8th International Conference on Renewable Energy Research and Applications (ICRERA), Brasov, Romania, 2019, pp. 910-915.

[20] F. Senani et al., "A Complete Modeling and Control for Wind Turbine Based of a Doubly Fed Induction Generator using Direct Power Control," International Journal of Power Electronics and Drive Systems (IJPEDS), vol. 8, pp. 1954-1962, 2017.

[21] A. Haruna, Z. Mohamed, M. Efe, and M. Basri, "Improved integral backstepping control of variable speed motion systems with application to a laboratory helicopter," ISA Transactions, vol. 97, pp. 1-13, 2020.

[22] S. Sastry, "Lyapunov Stability Theory," Interdisciplinary Applied Mathematics, pp. 182-234, 1999.

[23] M. Makhad, M. Zazi, and A. Loulijat, "Nonlinear control of WECS based on PMSG for optimal power extraction," International Journal of Electrical and Computer Engineering (IJECE), vol. 10, no. 3, pp. 2815-282, 2020.

[24] O. Boughazi, "Sliding Mode Backstepping Control of Induction Motor," International Journal of Power Electronics and Drive System (IJPEDS), vol. 4, no. 4, pp. 481-488, 2014.

[25] W. Ayrir and A. Haddi, "Fuzzy 12 sectors improved direct torque control of a DFIG with stator power factor control strategy," International Transactions on Electrical Energy Systems, vol. 29, no. 10, 2019. 